\title{
Yellow-Blue Collars: American Labor and the Pursuit of Swedish Policy, 1961-1963
}

\section{Byron Z. Rom-Jensen}

Aarhus University

\begin{abstract}
This article studies the Kennedy administration's labor market policies as a case of lesson drawing during a transnational moment in the early 1960s. With the election of Kennedy, leaders in the labor movement rose to positions of policymaking influence, in the process reimagining the United States' political and economic landscape. This spirit of reform led to the embrace of Sweden's solidarity wage policy and Rehn-Meidner model as lessons on how to balance full employment, economic growth, and a powerful labor movement. However, Secretary of Labor Arthur Goldberg and Walter Reuther of the United Automobile Workers found implementing Swedish policies to be more difficult than they expected, even with the support of a sitting president. Their experiences demonstrate the possibility for policy diffusion from small states to the United States over a short period, as well as its risks and limitations.
\end{abstract}

Keywords: lesson drawing, Rehn-Meidner, Walter Reuther, Swedish model, labor movement

\section{Introduction}

On 20 December 1962, Walter Reuther, the enterprising president of the powerful United Automobile Workers union (UAW), received a note from Nat Weinberg, his trusted intellectual advisor and head of the UAW's Special Projects Department, regarding a brewing conflict abroad. Having received troubling news from Sweden, where management at the new IBM factory was resisting Swedish unionization efforts, Weinberg begged his boss to intercede with Thomas Watson, Jr., the American CEO of IBM, about allowing the plant to be unionized. Surely, Weinberg reasoned, "con- 
sidering the responsible attitudes of the Swedish trade union movement," Watson could have no grounds to resist. ${ }^{1}$

Weinberg's letter to Reuther was just one of the many circulating amongst US labor leaders during the 1960s that shared images of the Scandinavian labor movement as a rational, powerful institution and of Nordic industrial policy as modern, effective, and beneficial. Yet, such widespread dissemination of a single positive outlook on Scandinavia begs important questions. From where did "labor-liberals," a combination of progressive Democrats and union officials, derive such a potent image of Swedish labor peace? And, more importantly, why would Americans like Weinberg and Reuther care about defending its existence?

These questions structure my examination of a transnational moment in the early 1960s when Scandinavian industrial policy became an influential model for American labor relations. Labor historians have traditionally attempted to understand the motivations of labor-liberals through international comparison, alternatively linking the goals of figures like Walter Reuther and Arthur Goldberg with Germany, France, and Sweden.2 These comparisons can obscure the actual desires of these leaders, who jointly looked towards Scandinavian policy to define and defend their interests, albeit in ways that occasionally proved contradictory with both the original Scandinavian methods and the goals of other labor-liberals. Therefore, instead of contrasting national systems, I track the numerous interactions and intersections of American and Scandinavian labor to explore how and why actors associated with the Kennedy administration tried to import Scandinavian policy across the Atlantic. As a form of lesson drawing, these attempts also gave a space for Nordic leaders to craft an image of their homelands for American audiences, determining which qualities best represented their experiences and ensuring that this "Scandinavian image" was in fact a "Swedish image." By etching the contours of American interest in Scandinavian policy, I further gauge its impact in the United States' decision-making and determine the causes for the unraveling of this transnational moment. In both its hopeful beginnings and disappointing endings, this transnational moment reveals a potential, and ultimately rejected, turning point in American history, a road not taken.

1 Nat Weinberg to Walter Reuther, 20 December 1962, UAW Research Department: Special Projects Collection, Box 128, Folder 3, Reuther.

2 Boyle, UAW, 149; Stebenne, Arthur J. Goldberg, 152-53; Lichtenstein, Walter Reuther, 337-38; Lichtenstein, State of the Union, 134. 
This paper begins by reviewing previous scholarship on the transnational circulation of images of Scandinavia and arguing the significance of a lesson drawing perspective. Next, I compare industrial policy in the USA and Scandinavia in 1960, thus situating American interest in Scandinavia. Following this, I examine two areas where Americans drew lessons from Scandinavia: collective bargaining and active labor market policy. Then I place these findings in the context of transnational movements in the early 1960s, including exploring why Sweden dominated American attention and the ultimate impact of Scandinavian lessons. Finally, I discuss the end of this transnational moment and its meanings.

\section{Images and Lessons from Scandinavia}

Despite discrepancies in size, material resources, and global reach, the attraction of Scandinavian policy in the US has inspired an extensive body of historical work examining a process of circulation, in which self-images and foreign images of the Scandinavian countries spread, "in a mutually reinforcing way." 3 This mechanism turns Scandinavia into "a mediated region" of "discursively maintained concepts," the temporal nature of which scholars have shown to great effect. ${ }^{5}$ As is implied by "mediation," intellectual or media actors produce these images and shape them with their own "strongly held convictions and ideals." Such representations attract both producers and consumers because of their viability as visions of modernity, triangulating local developments through the lens of potential futures abroad. ${ }^{7}$

Using this framework of mediation, historians have raised questions about why Scandinavian images circulate. A common explanation rests on the actions of the Scandinavian states themselves, who deployed posi-

\footnotetext{
Andersson and Hilson, "Images of Sweden," 222.

Harvard and Stadius, "Communicative Perspective," 1-2.

As an example, see, Marklund, "The Social Laboratory."

Harvard and Stadius, "Communicative Perspective," 6.

7 Andersson, "Nordic Nostalgia," 234; Musiał, Tracing Roots."plainCitation":"Andersson, "Nordic Nostalgia and Nordic Light," 234; Musiał, Tracing Roots of the Scandinavian Model."\},"citationItems" :[\{"id": 1291,"uris":["http://zotero.org/users/1192408/items/X852WXHE"],"uri":["http://zotero.org/ users/1192408/items/X852WXHE"],"itemData":\{"id":1291,"type":"article-journal","title":"Nordic Nostalgia and Nordic Light: the Swedish model as Utopia 1930-2007","container-title":"Scandinavian Journal of History","page":"229-245","volume":"34","issue":"3","source":"www-tandfonline-com. ez.statsbiblioteket.dk (Atypon
} 
tive representations of their systems as a means of public diplomacy and branding. 8 Less frequent are studies of the American context for such circulations, despite recognition that the US's "specific domestic questions" determined the extent and nature of image proliferation.9 Very rarely have historians taken the next step and analyzed how Scandinavia served as a practical model for American emulation, perhaps because some scholars have questioned its worth as a subject of academic attention.10

To undertake such a study, it is therefore necessary to appropriate a framework for understanding the mechanism by which one nation transfers policy from another. Lesson drawing theory satisfies this need. Unlike coercive or convergence processes, lesson drawing is a voluntary process, where actors seek answers from abroad, often with a bounded rationality that accounts for structural and circumstantial constraints. The concept of rationality best fits with the intent of actors in the United States to draw upon the policies from the smaller Scandinavian states. According to Richard Rose, policymakers are the primary performers of lesson drawing. Facing discontentment with the status quo at home, politicians and other decision makers undertake a "problem-oriented search" abroad.11 Although lessons are generally drawn from political systems believed to have been particularly successful in dealing with an issue - in other words, a search for best practice - other factors can enhance the appeal of a foreign state: similarities in resources, preexisting interdependence, and ideological compatibility. Rose finds the last aspect particularly important, as, "There is little point in social democratic policymakers looking for lessons from a country governed by adherents of free enterprise, for even if programme means are found to be transferable, programme goals may be unacceptable."12

International similarities between states are not the only factors that facilitate (and potentially hinder) lesson drawing. A major condition for successful lesson drawing is the existence of "green field" sites: policy areas

8 Marklund, "A Swedish Norden"; Marklund and Petersen, "Return to Sender"; Glover, National Relations; Kastrup, Med Sverige.

9 Stadius, "Happy Countries," 242; Logue, "The Swedish Model," 166-67.

10 Houe and Rossel, Images of America, ix. The most studied attempt to "import" Scandinavian political products is the 1936 Inquiry on Cooperative Enterprise, of which Piebe Teeboom's unpublished $\mathrm{PhD}$ thesis gives the best account. Teeboom, "Searching."

11 Rose, Learning, 5 .

12 Rose, “Ten Steps," 8, 18.12,23]]\}\},"locator":"8, 18”'\}],"schema":"https://github.com/citation-style-language/schema/raw/master/csl-citation.json"\} 
that have been largely unregulated or overlooked. Therefore, a lesson drawn from abroad would be building new institutions without having to first demolish embedded interests. On the other hand, "brown field" sites resist lesson drawing, as preexisting policies and public agencies impede its implementation.13 Successful lessons are studied, turned into a "cause-and-effect model," assigned symbolic value, and eventually become part of the domestic agenda.14 Unsuccessful lessons are ditched during this process.

In providing a defined procedure by which policymakers appropriate lessons from abroad, Rose offers a framework and a language against which to set labor-liberals' attempts to "learn" from Scandinavia. As Rose predicts, this American attention to Scandinavian policy took place amongst domestic discontentment with industrial policy and economic outlooks. The next section explores the diverging circumstances for labor unions in Scandinavia and the United States in 1960.

\section{Labor Policy in the 1960s}

Even before the decade known in Sweden as "the golden years," 15 optimism was high in Scandinavia. Improved productivity, wages, and trade balance reflected virtually continuous economic expansion since the Second World War and resulted in higher GDPs, both gross and relative, as well as better standards of living..$^{16}$ From the cellar of Western democracies at the beginning of the 1950s, Scandinavia's economies had risen to the top, aided by the prioritization of neo-corporatist industrial policy. ${ }^{17}$ A social democratic desire for social engineering made manifest, Scandinavian economic policy attempted to balance full employment and wage equality with the pressures of inflation, rather than following a prototypical Keynesian program of counter-cyclical, "stop-go measures." ${ }^{18}$ Instead, the Scandinavian states practiced centralized economic steering, called the Rehn-Meidner model in Sweden, which promoted an active labor market policy through public

13 Rose, “Ten Steps," 16.12,23]]\}\},"locator":"16"\}],"schema":’https://github.com/citation-style-language/ schema/raw/master/csl-citation.json"\}

14 Rose, Lesson-Drawing, 13-14; Rose, Learning, 23.

15 Östberg and Andersson, Sveriges historia, $25 \mathrm{ff}$.

16 Einhorn and Logue, "Can Welfare States," 9; OECD, "OECD.Stat."

17 Rasmussen and Rüdiger, Danmarks Historie, 147; Storing, Norwegian Democracy, 205; Hilson, Nordic Model, 66.

18 Hilson, Nordic Model, 69. 
spending on vocational training and retraining, as well as relocation programs. In Sweden, this latter goal produced a system of worker relocation to labor-hungry industrial areas, primarily in the country's southern region (earing it the nickname "All Must go South" [Alla Måste Söderut]), while in Norway and Denmark, subsidies and other incentives moved capital to labor-surplus regions so as to maintain their cultural independence and distinctiveness [Danish: Egnsudvikling]. ${ }^{19}$ This supply-side focus extended into a Swedish investment reserve fund aimed at directing private investment and augmenting spending in the event of an economic downturn. ${ }^{20}$ In Sweden, many of these policies were managed or directed by the Labor Market Board [Arbetsmarknadsstyrelsen, AMS], an entity principled on "modern state interventionism," with a tripartite leadership and a staff primarily recruited from labor. ${ }^{21}$

The success of the Rehn-Meidner model depended on a solidarity wage policy that demanded restraint from both trade unions and business interests in their wage and price setting. This was accomplished under a cooperative framework of centralized collective bargaining, known in Sweden as the "Spirit of Saltsjöbaden." Negotiations between labor and management took place without state arbitration, although government officials maintained relations and dialogue with both sides. To bolster these lines of communication, industrial leaders often gathered at the prime minister's countryside residence in Harpsund, giving the policy its name "Harpsunddemokratin" (Harpsund democracy). Throughout Scandinavia, with its high trade union density (72.1 percent in Sweden in 1960), labor proved powerful allies of the ruling Social Democrats. ${ }^{22}$ In exchange for expanded social programs and spending to benefit workers, including policies offering high levels of income replacement for the temporarily unemployed, the trade unions maintained restraint in their wage demands. ${ }^{23}$ Labor conditions in Scandinavia in 1960 were therefore centralized and generally peaceful, boasting conditions that gave private industry room to profit while nonetheless respecting the influence and demands of organized labor.

The trajectory for American trade unions since the war was less inspir-

Hilson, Nordic Model, 70; Rasmussen and Rüdiger, Danmarks Historie, 156.

20 Östberg and Andersson, Sveriges historia, 31; Rasmussen and Rüdiger, Danmarks Historie, 169.

21 Sejersted, Age of Social Democracy, 222.

22 OECD, "OECD.Stat."

23 Einhorn and Logue, "Can Welfare States," 9. 
ing. Despite a quick recovery from a recession in 1958 and later in 1961, unemployment in the US remained highest amongst OECD countries from 1960-1964, around 5.5 percent. Comparatively, Scandinavian unemployment over the same period ranged between 1.2 percent (Sweden) and 2.2 percent (Denmark and Norway). ${ }^{24}$ The US lacked a coherent central strategy to deal with issues like automation and, for many Americans, a copacetic economic situation disguised structural uncertainties within the American economy. Such trends were worrying for labor-liberals, as were the effective attacks by conservative and business forces upon American unions since 1945. While the New Deal, and in particular the 1935 Wagner Act, had established the labor movement as participants in "a new political order" with the Democratic Party, the origins of the "labor-liberal" moniker, it also left the unions open to attack during the conservative swing in American politics following World War II..$^{25}$ The Taft-Hartley Act, which eliminated sympathy strikes and closed shops and forced union officers to sign a non-Communist affidavit, effectually demilitarized the unions by weeding out labor's radical edge and outlawing some of its most effective weapons.

The apathetic attitude of the Eisenhower administration to organized labor and the merger of the two largest employee federations in the US, the American Federation of Labor (AFL) and the Congress of Industrial Organizations (CIO), in 1955 extinguished the last gasp of union radicalism. The merger also set the stage for one of the major labor rivalries of the mid-century, between Reuther, the social democratic president of the CIO and UAW, and George Meany, head of the AFL. The new umbrella organization commanded formidable economic power, especially as union density continued to increase, although the US's 30.9 percent in 1960 still fell well short of Scandinavia. ${ }^{26}$ However, shifts in labor's methods, such as the reliance on the ritualized strike, and goals, especially prioritizing contractual benefits over wider social programs, threatened to "ghettoize" labor's influence in the political realm. ${ }^{27}$

Yet, the election of John F. Kennedy opened new possibilities for the movement. Having organized their unions behind the Massachusetts senator, labor leaders expected to assert a level of influence over the presidency

24 Nickell, Nunziata, and Ochel, "Unemployment," 2.

25 Plotke, "The Wagner Act," 153; Boyle, Organized Labor.

26 OECD, "OECD.Stat."

27 Lichtenstein, State of the Union, 125-129; Dubofsky, The State \& Labor, 212ff. 
unknown since Roosevelt's 1936 reelection. Kennedy certainly seemed to reciprocate, appointing Arthur Goldberg his Secretary of Labor. The choice of Goldberg, former counsel and strategist for the CIO and United Steelworkers of America, put a knowledgeable and cosmopolitan leader friendly to organized labor in charge of administering American industrial relations. Additionally, Kennedy selected Esther Peterson, his CIO representative in Washington, as Assistant Secretary of Labor and head of the Women's Bureau. The USA seemed on the brink of a new age of labor policy.

\section{Defining the Public Interest}

It was in this atmosphere of optimism and prospective gains that America's labor-liberals looked to ideas from Scandinavia to reinvigorate labor's fortunes. Partially, the decision to draw lessons from Scandinavia owed to the discreditment of other European models, such as the British system of decentralized shop floor activism, which lost its legitimacy amongst the centralized and demilitarized American labor movement. ${ }^{28}$ However, more important was the US's long history of appreciation for Scandinavian industrial relations, which seemed to function with minimal friction and loss. Following the ravages of the Great Depression, Americans had looked to Scandinavia, and particularly Sweden, for "industrial democracy" in action. ${ }^{29} \mathrm{~A}$ vision of accommodating and democratic relations enticed Americans, especially when Marquis Childs, whose Sweden: The Middle Way had been a bestseller, published This Is Democracy: Collective Bargaining in Scandinavia in $1938 .{ }^{30}$ His description of "middle way" industrial pragmatism resonated with Americans. Proponents included Franklin Roosevelt, who, the same year as Childs's book, placed Sweden on the agenda of a commission investigating collective bargaining in Great Britain. Although such studies were somewhat disrupted by war and subsequent reconstruction, during which Scandinavian unionists instead drew upon technical knowledge from the US, ${ }^{31}$ the view of Scandinavia as possessing a uniquely "mature" and "good" labor policy persisted. ${ }^{32}$ Indeed, in 1951, economist

28 Tolliday and Zeitlin, "Shop Floor Bargaining," 219-20.

29 Stadius, "Happy Countries," 246.

30 Childs, This Is Democracy.

31 Fossat, "American Way."

32 Lester, "Reflections," 375; Clayton, “Collective Bargaining," 109. 
Charles Myers predicted a convergence between US and Swedish industrial policy "in another ten years." Yet Myers failed to foresee that the act of translating foreign ideas opened them to interpretation, and hence difficulties in their enactment. ${ }^{33}$

Goldberg was therefore certainly not alone when he began studying Sweden's industrial relations system early in his tenure as Secretary of Labor. He believed the arrangement held answers "for eliminating the problems that increasingly threatened the post-war social contract" between labor and management ${ }^{34}$ In April 1961, the day after meeting Tage Erlander, the prime minister of Sweden, at a banquet in Washington D.C., Goldberg announced his intentions to visit Sweden. ${ }^{35}$ While labor unrest at home forced Goldberg to cancel this first visit in July 1961, several deputies, including Esther Peterson, travelled to Sweden to study labor policy, especially training and retraining programs.$^{36}$ Following this false start, Goldberg received a formal invitation from Erlander to visit Sweden, which the secretary accepted. On 18 September 1961, Goldberg departed Washington for a two-week tour of training facilities and industrial institutions throughout Scandinavia, Finland, and the Netherlands. The highlight was a meeting of government, labor, and business leaders at the prime minister's residence in Harpsund. Witnessing a demonstration of Harpsund democracy, Goldberg read a prepared statement in Swedish, telling his audience, "We have much to learn from you." 37

The philosophy of "mutual respect" between employer and employee representatives concurred with Goldberg's own views on the proper atmosphere of industrial relations, ${ }^{38}$ which he hoped to preserve in the face of the "hardening of attitudes" in collective bargaining.39 The secretary was a product of the mid-century labor movement, which structured itself around centralized labor leaders representing an obedient rank-and-file, a change from the traditional grassroots autonomy of American locals.40 The place-

\footnotetext{
33 Myers, Industrial Relations in Sweden, 112.

34 Stebenne, Arthur J. Goldberg, 263.

35 "Goldberg Plans."

36 Shelton, "Swedish System."

37 Stebenne, Arthur J. Goldberg, 263.

38 "Goldberg Hails Swedes."

39 Opotowsky, The Kennedy Government, 105.

40 Berendt, Cornfield, and Edelman, “Arthur J. Goldberg’s Legacies,” 698; Oettinger, "Collective Bargaining," 250 .
} 
ment of bargaining responsibility within the leadership of labor internationals and federations fit with the "highly organized" and centralized nature of Scandinavian bargaining, in which confederated employee and employer organizations negotiated general contracts.41 As Goldberg announced at a press conference the day after returning to Washington, his trip to Scandinavia had convinced him that the freedom of collective bargaining was sacred, but:

That the very best way to achieve this ultimate result is by having responsible management and responsible labor unions discharge their common responsibility to the public, and that the more authority there is in employers' organizations and in labor unions to function in this area, and the more acceptance there is on both sides of each other, the better hope that we have that their results will be compatible with the overall public interest. ${ }^{42}$

In emphasizing the primacy of the public interest, which would come to mean wage restraint amongst the unions and price control amongst the employers, Goldberg's statement was not notably original. Eisenhower's administration had likewise prioritized maintaining reasonable wages and prices in privately negotiated contracts to avoid passing costs on to the consumer. ${ }^{43}$ However, even whilst praising Sweden's respect for private bargaining, Goldberg was about to demonstrate that he had also picked up another lesson from Scandinavia: the need for the state to take responsibility when labor and capital refused to act responsibly.

Despite the generally subordinate role of the state in Swedish industrial relations, especially with the absence of compulsory arbitration, the government nonetheless played an active part in overseeing the centralized bargaining process, meeting with economic leaders at Harpsund and providing labor mediation when necessary. The procedure demonstrated the government's willingness to work with representatives of labor and business to ensure peaceful and profitable decisions. Yet, when Goldberg tried to commend the system at his press conference, he was instead buffeted with questions about the upcoming negotiations in the steel industry. The strike of the steel unions in 1959 over provisions for managerial rights had been devastating and resulted in the weakening of the industry as a whole

41 Clayton, "Collective Bargaining," 98.

42 Arthur Goldberg, "Press Conference," 2 October 1961, Folder: Set VI, II:57, Goldberg.

43 Oettinger, "Collective Bargaining," 233. 
when American companies turned to cheaper sources of steel abroad. Now, Goldberg declared the necessity of "stability and settlements" and worked to broker a contract that froze both wages and prices, meant to reinvigorate steel's international competitiveness ${ }^{44}$ Indeed, in a report to Kennedy about his Swedish visit, Goldberg recommended that restraint amongst labor and management, imparted by an awareness of the global market, "may rapidly be replicated in the United States." 45 Goldberg accordingly parlayed his Scandinavian experiences into a policy that would have the federal government take an active, continuous, and direct role in defining the national interest in private negotiations. Goldberg would later explain that it had not been his initiative to insert a federal role into "any dispute with nationwide impact." Instead, he recounted, "I was a Secretary of Labor for a very activist President." 46 However, subsequent historians have noted Kennedy's apparent indifference to the plans of the labor-liberals, although he was supportive of Goldberg in the calamity that followed ${ }^{47}$ Rightfully then did Business Week declare this new policy the "Goldberg doctrine." 48

The interventionism of Goldberg's Labor Department held superficial similarities to the Harpsund democracy of Sweden, but the difference in responses highlights the problems with such surface appearances. Labor historian Melvyn Dubofsky describes how American labor, in their coalition with the Democrats, was willing to accept some degree of regulation, much as Western European trade unions were willing to restrain themselves to accommodate their social democratic allies. ${ }^{49}$ But Goldberg's proposed government oversight over private negotiations worried labor leaders. Upon hearing Goldberg announce the Kennedy administration's intention to "define and assert the national interest in collective bargaining," George Meany protested that the secretary was "infringing on the rights of free people and free society." ${ }^{50}$ At the AFL-CIO convention in December, the

44 Arthur Goldberg, "Press Conference," 2 October 1961, Folder: Set VI, II:57, Goldberg; Lichtenstein, State of the Union, 132, 135; Stebenne, Arthur J. Goldberg, 291.

45 Arthur Goldberg, "Draft: Secretary's Report on Sweden," 6 December 1961, MC 450, Folder: 1228. Schlesinger.

46 Quoted in Sorensen, Kennedy, 440.

47 Perlstein, Before the Storm, 34; Lichtenstein, Walter Reuther, 357. In fact, Kennedy was generally illiterate in most economic matters. Reeves, President Kennedy, 54, 294-95.

48 "A Leader Must Lead."

49 Dubofsky, The State \& Labor, 217, 219.

50 "Keep Hands Off." 
audience, cautious about state authority after a decade and a half of conservative attack from Washington, booed Goldberg when he brought up wage restraint. ${ }^{51}$ Even Walter Reuther, generally more sympathetic to corporatist arrangements, publicly warned the administration that unions would guard against losing their ability to make collective agreements. ${ }^{52}$ Very quickly, it became apparent that Americans viewed the lessons from Scandinavia as a path leading to just such a loss of control, an assumption Goldberg learned firsthand. The day after his press conference, two days after returning from Europe, Goldberg gave speeches before both employee and employer organizations describing his realization while in Scandinavia that both sides "must...operate with enlightened polices of cooperation in place of conflict, of self-interest measured and enlightened by the national interest of which they are a part." ${ }_{53}$ However, as the press reported the next day, the secretary "got his coolest reception at both conferences on this point." ${ }^{4}$

\section{Freedom and Democracy in Labor Market Policy}

Despite the limited and critical reception that Scandinavian lessons in collective bargaining received, other avenues for lesson drawing from Scandinavia remained open. Most notably, Kennedy and the labor-liberals saw the active labor market policy of the Rehn-Meidner model as a chance to overhaul government measures in combating unemployment. Representative of this new logic was the AMS, "a powerful public body with a budget to match." ${ }^{55}$ The AMS administered employment programs, including services for training, retraining, and worker mobility. For mid-century progressives, such programs promised solutions to growing economic inequities and the long-term effects of automation on employment. Thus, in 1964, Senator Paul Douglas, who had passed federal legislation in 1961 and 1962 bringing jobs and retraining programs to depressed areas, commissioned a Joint Economic Committee report on the Unemployment Programs in Sweden that gave a favorable view of Sweden's "enviable record of unemployment"

51 Dallek, An Unfinished Life, 482-83.

52 Strout, "Growth Rate."

53 Arthur Goldberg, "Address before the NAM," 3 October 1961, Folder: Set VI, II:57, Goldberg.

54 Townsend, "People at Work."

55 Hilson, Nordic Model, 70. 
and success in "dampening boom conditions" and raising productivity. ${ }^{56}$ The attraction was widespread. In February 1965, American ambassador to Sweden J. Graham Parsons described a "procession" of American visitors to the AMS, inspired by official United States interest in employment services and retraining activities. ${ }^{57}$

American debates on the AMS were even more intense at the beginning of Kennedy's administration, as the role of Scandinavia in the President's Advisory Committee on Labor-Management Policy (PACLMP) attests. The creation of Goldberg, the PACLMP was intended to be a "consensual" body - made up of members from labor, business, and the public - that would investigate and make recommendations, "to promote collective bargaining, industrial peace, sound wage and price policies, and higher living standards." ${ }^{58}$ In its tripartite membership and desire for centralized steering, the PACLMP resembled the AMS, although its advisory nature meant that it possessed no ability to actually implement its recommendations. Still, the PACLMP existed as a testament to labor's belief that the previous bonds of industrial power had loosened and a rewriting of multilateral decisionmaking was eminent.

One member of the PACLMP particularly enthusiastic about its corporatist possibilities was Walter Reuther. Reuther had seen such a setup work in Sweden, where he was a frequent visitor and a favorite of the Scandinavian media, who basked in the labor leader's praise..$^{59}$ Encompassing ambitions for tripartite planning stretching back to the Second World War, "Reutherism," as Reuther's flexible vision for America became known, "encapsulated a vital strand of social democratic thought." It linked union power with government authority in a corporatist arrangement "designed to reorganize American capitalism within a more stable and humane framework." 60

Aiding this convergence in goals between Reutherism and Swedish neocorporatist policy was the professional and personal relationship of Reuther and Arne Geijer, president of the Swedish Trade Union Organization (LO). Geijer regularly hosted Reuther on his trips to Scandinavia, a favor Reuther

56 Schnitzer, "Programs," iii, 31.

57 J. Graham Parsons to State Dept (A-516), 12 February 1965, NARA, RG59, Entry A1 1613, Box 2678, POL 2-3 SWE.

58 Stebenne, Arthur J. Goldberg, 238; Maraniss, Once, 22.

59 Vincent P. Wilbur to State Dept (Desp. No. 399), 3 December 1959, NARA, RG84, Entry UD 2386, Box 64, 560.1 Trade Unions.

60 Lichtenstein, Walter Reuther, 155. 
returned during Geijer's many trips to the US. Both Geijer and Reuther were internationalists, believing in the possibilities of a global labor movement, and Reuther backed Geijer's successful bid to become head of the International Confederation of Free Trade Unions in $1957 .{ }^{61}$ More than allies, the two were personally close: planning fishing trips and vacations in Florida, visiting each other with families in tow, and hosting each other's daughters during summers abroad. As Reuther biographer Nelson Lichtenstein surmises, Geijer was, "one of his [Reuther's] few genuinely intimate friends." 62

The allegiance between American and Swedish labor served as a catalyst for proposals that Geijer and other Swedish leaders appear before the PACLMP to testify on the Rehn-Meidner system. The formal invitation came from Goldberg, who delayed inviting the Swedes until after the committee had defined the problems facing the US labor market, ${ }^{63}$ notwithstanding Reuther's calls for a study of Sweden since the second meeting. ${ }^{64}$ On 2 October 1962, a distinguished commission arrived in the Fish Room of the White House to testify on the Swedish system of industrial relations: Geijer; Bertil Kugelberg, director of the Swedish Employers Association; and Ernst Michanek, Undersecretary of Labor. Under the gaze of the massive sailfish mounted on the wall, they met with Goldberg, present despite recent elevation to the Supreme Court, Reuther, and a number of other notable American leaders.

All three guests began with prepared statements that attempted to establish the ideological compatibility between Sweden and the US. Despite a common focus on the benefits of cooperative industrial relationships and mutual recognition of labor, business, and government, the delegation employed conflicting signifiers and meanings to praise the Swedish model. Kugelberg leaned on the term "freedom," meaning free enterprise, to explain how the goals of the two countries were the same. Geijer, on the other hand, stressed the "democratic" nature of the Swedish corporatist system, relating how unions had gained the right to influence economic policy. Both Kugelberg and Geijer placed their ideology within a Cold War context, describing their support for the preservation of "freedom" and "democracy"

61 Carew, Walter Reuther.

62 Lichtenstein, Walter Reuther, 338.

63 Stebenne, Arthur J. Goldberg, 264.

64 “Minutes of PACLMP Meeting," 1 May 1961, NARA, RG 220, Records of the PACLMP, Entry A1 34140, Box 11. 
against "dictatorship." On another point they agreed: a fundamental part of the Swedish system was keeping government out of wage negotiations while maintaining contact with public representatives in other forms. As a government representative, Michanek was more reticent regarding the noninterventionist approach of the state, noting the AMS's role as a national mediation service. Nonetheless, Michanek, combining the signifiers of his two countrymen, described how the "high degree of responsibility in freedom" to negotiate wages without government interference was "part, as it were, of our democratic ideology." 65

In their statements, the Swedes seemed reluctant to comment on how Swedish policy might benefit the US; conversely, they were quick to point out places of national divergence. Instead, it was the Americans, and particularly Reuther, who explicated on the meanings of Swedish policy for domestic conditions. In particular, the PACLMP questioned their guests about employment measures like labor mobility and the investment reserve. Reuther's desire to see the government take a more active role in managing the economy led him to probe Kugelberg about whether the AMS focused on broad aspects of economic planning. ${ }^{66}$ When Kugelberg subsequently affirmed that it did, the UAW president doubled down on this idea by declaring "that in the United States we have made greater progress on collective bargaining issues between labor and management than we have in the political arena." ${ }^{\prime 67}$ Reuther thereby mirrored Geijer's own description of "democracy" by envisioning an economy with a tripartite influence in policymaking. The election of Kennedy had opened the possibility for such imagining, as had Reuther's own convictions that, despite the "different historical backgrounds" of American and Swedish labor, "our basic aims are similar." 68

Even though the meeting with the Swedes provoked internal calls to study other foreign models, the PACLMP remained focused upon Sweden. Reuther was a driving force behind the retained interest, castigating the committee for not having done more with Swedish examples. ${ }^{69}$ A new del-

65 "Notes from Bertil Kugelberg's Remarks;" "Presentation by Ernst Michanek;" "Notes from Arne Geijer's Opening Remarks," 2 October 1962, NARA, RG 220, Records of the PACLMP, Entry A1 34140, Box 13.

66 Lichtenstein, State of the Union, 134-35.

67 "Minutes of PACLMP Meeting," 2 October 1962, NARA, RG 220, Records of the PACLMP, Entry A1 34140, Box 13.

68 Lichtenstein, Walter Reuther, 337-38.

69 "Notes from PACLMP"; "Minutes of PACLMP," 10 December 1962, NARA, RG 220, Records of the 
egation of Swedes testified before the PACLMP on 25 March 1963, this time to specifically investigate the "various contra-cyclical policies and programs currently utilized in Sweden."70 Whereas the tripartite delegation was composed of venerable industrial leaders, the second delegation skewed younger: Curt Nicolin, head of Sweden's largest energy concern, and Krister Wickman, Undersecretary of Finance. The second delegation, especially Nicolin, proved more willing to criticize the Rehn-Meidner model and make recommendations for the US. During the meeting, new Secretary of Labor Willard Wirtz asked the inevitable question about how Sweden's size disparity affected its usefulness as a model for the US. Wickman granted this differential, but returned to a favored symbol, indicating the relatively even income distribution and democratic systems of both nations to underscore Sweden's value as a source of lessons. Nicolin was more circumspect, suggesting that the Swedes" "strong tradition of paternalism" was "conducive to cooperation" in a way not possible in the US. Reuther agreed with this conviction. However, the UAW president turned it into a criticism of the US's preference for concentrating employment policy in the private sphere. Eventually, Wirtz asked the delegation if they expected future developments in American labor policy "to go in their direction, and, if so, do they expect such moves to come about through governmental or private action?" Wickman answered cautiously, speculating on a reconciliation of American interest groups, similar to Sweden. ${ }^{71}$

Such predictions confirmed American labor-liberals' belief in the need for a parity of influence and responsibilities between labor and management. Greater control of economic steering, placed in a tripartite board that recognized employee representatives as equals of the employers, would be step towards such a reordering. To that end, Reuther kept up the rhetoric on Scandinavia, distributing favorable Toronto Star and OECD profiles on Swedish policy amongst the PACLMP members. As Weinberg commented upon forwarding the Toronto Star article to Reuther, Swedish policy had "enormous possibilities" for "a powerful labor movement." 72

PACLMP, Entry A1 34140, Box 14.

70 Eugene P. Foley, "White House Briefing," 15 March 1963, NARA, RG 220, Records of the PACLMP, Entry A1 34140, Box 15.

71 "Minutes of PACLMP Meeting," 25 March 1963, NARA, RG 220, Records of the PACLMP, Entry A1 34140 , Box 15.

72 Nat Weinberg to Walter Reuther, 31 January 1963, UAW Research Department: Special Projects Commission, Box 128, Folder 3, Reuther. 


\section{Transatlantic Exchanges and Lesson Drawing}

The discussion of Swedish policy in the high-profile PACLMP was part of a larger process of transnational movement and communication in the early part of the 1960s that led historian Carl Marklund to proclaim it the, "high tide of American interest in Sweden."73 Delegations from Sweden were frequent sights in Washington during that period. In October 1962, the directorate of the Swedish white-collar union funded their own trip to the US to share their "successful pattern" of unionism, the first international trip taken by the entire directorate of a leading union. ${ }^{74}$ Moreover, the delegation of Geijer, Kugelberg, and Michanek was much in demand, visiting the Council of Economic Advisors, the Chamber of Commerce, members of the AFL-CIO, the President's Commission on the Status of Women (PCSW), and UAW headquarters during their October 1962 tour. $^{75}$ Following their session with the PCSW, Esther Peterson, who had initiated the committee and herself lived in Sweden for four years, publicly declared her support for a federal "Five Year Plan" modeled after the 1960 Swedish agreement between employers and unions to abolish gendered salary discriminations. ${ }^{76}$ The delegation returned to the US the following year to testify before the Senate Committee on Labor and Public Welfare, on which Senator Douglas was chairman.

Outside of the invitations of the tripartite delegation, the deluge of Scandinavian visits to the US might seem to signal a unidirectional interest extending from Europe to the US. On the contrary, influential American policymakers conducted their own tours of Scandinavia. Senator Joseph Clark travelled to Sweden, Denmark, and Romania in preparation of the report for his "Subcommittee on Housing for the Elderly" and came away impressed with the "variety of accommodations and services." 77 Senator Maurine Neuberger, chairman of the PCSW's Committee on Social Insurance and Taxes, flew to Sweden in September 1962 to investigate legislation to improve equality for women, particularly regarding childcare centers for working women. ${ }^{78}$ So great was the demand for study tours of Scandinavia,

73 Marklund, “A Swedish Norden," 274-75.

74 Jorma L. Kaukonen to State Dept (A-301), 9 October 1962, NARA, RG84, Entry UD 3195, Box 159, 560.1.

75 Geijer also made a nationally broadcast speech in 1960. Marklund and Petersen, "Return to Sender," 253.

76 Cheshire, "Equal Pay."

77 Special Committee on Aging, "Housing for the Elderly."

78 "Washington Reports to the People," 29 July 1962, MC 450, Folder: 851, Schlesinger. 
and particularly Sweden, that Reuther apologized to Geijer and assured his friend that it was not his intention "to turn the LO into a travel agency." 79

That Sweden became the primary Scandinavian destination for so many Americans is worth lingering over; after all, Scandinavian labor market policy existed in Denmark and Norway as well, and sometimes in forms more appealing to American progressives than in Sweden. Paul Douglas, for example, sought to draw industries into depressed areas rather than encourage labor mobility, a goal more aligned with policy in Denmark and Norway. Yet, his committees chose to study Sweden. ${ }^{80}$ Several explanations may account for why Sweden dominated the American spotlight in the early 1960s. First, Swedish economic indicators in unemployment, productivity, and GDP were better than in Denmark or Norway, and the country's larger population made it slightly more resilient to charges of small state exceptionalism. Second, starting in the 1930s, and especially after Sweden: The Middle Way, Americans had a history of treating Sweden as the best representative of a "Scandinavian model." Third, previous scholars have noted Sweden's public diplomacy strategy, including deploying branding and image circulation, which culminated in the 1960s with the Face of Sweden television show and the Meet Modern Sweden cultural tour throughout the American Midwest. By building a positive image of their nation, most notably through the well-funded American-Swedish News Exchange, Sweden "evolved into the archetypical welfare state" in the US's reckoning. ${ }^{81}$ Finally, the personal relationship of Reuther and Geijer gave the nation an influential advocate in the highest echelon of US politics and the backing of the UAW, a powerful labor organization that, during Kennedy's election, demonstrated its ability to enact political change. ${ }^{82}$ Although the UAW president maintained contacts with leaders in other countries, including Denmark and Norway, Reuther's connections with Sweden represented an unmatched pipeline of news, ideas, ideology, and strategy.

However, it is not enough to record that Sweden came to the forefront of American interest, we must also judge what effect this elevation ultimately

79 Walter Reuther to Arne Geijer, Apr 26, 1965, UAW President's Office, Box 461, Folder 6, Reuther.

80 Levitan, Federal Aid, 240; Bernstein, Promises Kept, 167-72.

81 Marklund, "A Swedish Norden,” 274; Marklund and Petersen, "Return to Sender"; Glover, "Imaging Community."

82 Boyle, $U A W, 145-46$. 
had on American labor policy. Unfortunately, as Marklund and Klaus Petersen caution when following the transmission of Swedish policies, "it is difficult to evaluate their political impact," especially since lessons from abroad may lose rhetorical orientation towards their native country during the policymaking process. Therefore, it is perhaps best to examine the eventual fate of the programs and arrangements that drew lessons from Scandinavia. The Goldberg-brokered contract in the steel industry collapsed disastrously in April 1962 when U.S. Steel refused to freeze its prices, leading Kennedy to lash out that, "My father always told me that all businessmen were sons of bitches, but I never believed it until now." The double-cross, combined with subsequent negative press of the White House's "ruthlessness" and an accompanying stock market breakdown, convinced the administration against further formal attempts to ensure that labor and management respected the public interest. ${ }^{83}$ Goldberg's other project, the PACLMP, could not capitalize on a strong start and became "bogged down over both substantive and procedural matters," leaving Goldberg (and Reuther) "to reconsider his dream of emulating the Swedish corporatist system." ${ }^{84}$ The inability of its members to embody the necessary spirit of cooperation and communication ultimately doomed the commission, as rival camps set up around Reuther, Meany, and Ford president Henry Ford II. ${ }^{85}$ Although the PACLMP would not formally dissolve itself until 1969, its potential to reconstruct economic democracy in the US was dead long before. The PCSW, on the other hand, had more success, having both a specific task and a deadline to complete it. Their final report, entitled American Women, recommended childcare services for children from all economic levels, with costs scaled to parents' ability to pay, outside contributions, and public appropriations ${ }^{86}$ Furthermore, Sweden served as a direct example of how mothers and wives should possess property rights, an arrangement not guaranteed throughout the US. Nonetheless, there was no mention of Peterson's five-year plan.

Even with the PCSW's recommendations of some Swedish practices, the outcome of the transnational moment was generally disappointing for

83 Lichtenstein, State of the Union, 135-36; Reeves, President Kennedy, 302-3; Stebenne, Arthur J. Goldberg, 298; Heath, John F. Kennedy, 83.

84 Berendt, Cornfield, and Edelman, "Arthur J. Goldberg's Legacies," 721.

85 Maraniss, Once, 214-15.

86 PCSW, American Women, 18-20. 
labor-liberals. Instead of being recast in the image of Sweden, American labor relations and policy continued largely as before, with unemployment and inflation remaining significant concerns.

\section{Conclusion: The End of a Transnational Moment}

Despite the ultimate failures to enact Scandinavian policies in the United States, the transnational moment of the early 1960s represented a major incidence of lesson drawing, with Washington awash in Scandinavian experts and ideas. Yet, by the end of the decade, study tours from Scandinavia far outnumbered their companion tours from the US. The roots of this decline can be traced both domestically and internationally, as changes in political and labor leadership and discord over the Vietnam War calcified attitudes on both sides of the Atlantic.

In the US, Lyndon Johnson, taking over the presidency from the assassinated Kennedy, proved less supportive of Swedish lessons. In one instance prior to the 1964 election, the president heard that his vice presidential candidate Hubert Humphrey was planning to attend a meeting of social democratic leaders in Harpsund, which Humphrey had previously attended in 1963 in the company of Reuther. Whereas Kennedy had given his blessing to the tour and asked for reports from Humphrey and Reuther, Johnson allegedly proclaimed, "O my God! Not a socialist summit!" The next summer, Reuther travelled to Sweden alone.$^{87}$ It is difficult to say whether Johnson truly believed that Sweden was socialist - after all he maintained a friendly relationship with Danish prime minister Jens Otto $\mathrm{Krag}^{88}$ - or whether he was merely worried about such an attack from Republicans. Either way, the new president's concern with the civil rights movement obviously far outweighed his interest in Scandinavian labor lessons, with the former dominating domestic discussion until the end of the decade. Reuther and the labor-liberals ended up spending much of their political and financial capital supporting civil rights, leaving little for other projects. Alongside the decline of the PACLMP and Goldberg's nomination to the Supreme Court, these developments deprived Scandinavia of its political momentum.

Regardless, as Parsons's comments about American visitors makes clear, 
interest in Scandinavia persisted into 1965. However, international developments took their toll during the second half of the decade. For some Americans observing Sweden, "the system of collective bargaining...lost its magic in the torturous negotiations of 1966," as the eventual contract expanded wages and benefits beyond forecasts for productivity, subsequently inciting concerns about inflation. ${ }^{89}$ Simultaneously, a Swedish teachers' strike demonstrated that industrial cooperation was not all encompassing..$^{90}$ Even more disastrous was the fallout from the Vietnam War. Besides creating a hostile diplomatic environment, high-level official travel between the US and Sweden waned amidst an atmosphere of political divergence. The communication that remained increasingly focused on the war's developments, as Reuther found out when he attended the second Harpsund meeting in 1965. Rather than a discussion about social democratic economic philosophy, the meeting produced a formal request by the European leaders that Reuther inform Johnson of their concerns about the war. ${ }^{91}$ Reuther defended the US's intervention in southeastern Asia at the meeting and during the early years of the war, but an increasingly critical stance during the latter-half of Johnson's administration exacerbated tensions between him and the stolidly pro-war Meany. In 1968, Meany successfully parried a powergrab by Reuther, resulting in the UAW permanently leaving the AFL-CIO. Thus, at the end of the decade, Reuther was no longer a dynamic national figure, but an embattled leader looking towards retirement..$^{2}$ His death in a plane crash in 1970 robbed the Scandinavian industrial policies of their most staunch American proponent.

Scandinavian attitudes towards the United States were simultaneously eroding due to the Vietnam War, coinciding with and perhaps facilitating major shifts in political power. Connections with the United States became a liability for political and economic leaders, as public opinion castigated them based on those connections. Amongst the most vocal critics were members of the anti-establishment youth movement, who accused the Scandinavian governments of having "abandoned their ideological commitment to socialist reform" and being "content merely to manage capital-

89 Turner Cameron, Jr. to Dept of State, (Stockholm A-708), 17 May 1967, NARA, RG59, Entry A1 1613, Box 2506, POL SWE-US.

90 Molin, "Sweden," 255-56.

91 Lewis Cariner to Victor Reuther, 27 August 1965, UAW President's Office, Box 463, Folder 6, Reuther.

92 Lichtenstein, "Walter Reuther," 300. 
ism rather than to reform it." 93 This interlacing of distrust in US foreign affairs with a rejection of the domestic status quo was apparent in 1968, when the streets of Stockholm resounded with demonstrators chanting "Tage och Geijer, Lyndons lakejer" [Tage and Geijer, Lyndon's lackeys]. ${ }^{94}$ Continued economic growth was no longer sufficient to justify the persistence of traditional cooperation and solidarity, as the Scandinavian Social Democratic parties were toppled one by one, until at last the Swedish Social Democrats lost control of the government in 1976 after 44 years in power. The result was a Scandinavian region that was less harmonious internally and externally, diminishing its usefulness as a model in American politics.

In accounting for the transnational moment's demise, one must also consider the role of over-saturation. As Scandinavian lessons became tied with labor-liberal goals in public debate, they came under attack by conservatives who accused the Scandinavian nations of being too small, too homogenous, and too socialist. ${ }^{95}$ Amongst them was Barry Goldwater, former Republican candidate for president, who used an image of Sweden to condemn the unseen costs of the Democrats" "pie-in-the-sky promises of socialism and of welfarism." ${ }^{96}$ Warranted or otherwise, such charges chipped away at the effectiveness of Scandinavian lessons.

Even with its passing, the transnational moment represented an important event in the history of American-Scandinavian relations. In it, American labor-liberals looked across the Atlantic to find a vision promising a reordering of American industrial relations, therein revealing the potential for immense policy diffusion over a short span of time. The American attention to Sweden, which seemed to permeate throughout Washington from 1961-1963, drew upon the space opened by Kennedy's election to reimagine the US's political and economic landscape, as well as the convergence of American and Scandinavian concerns about wages, prices, and inflation. Furthermore, as the Cold War limited the choices for lesson drawing, American progressives found in Sweden an example of how economic democracy could exist without sacrificing a system of free enterprise: "forethought" without "force." ${ }^{97}$ Eventually, labor-liberals' dependence on Scandinavian

93 Hilson, The Nordic Model, 49.

94 Carlbom, "Palme Och Geijer, Finfina Grejer."

95 Marklund and Petersen, "Return to Sender," 253.

96 Goldwater, "No Free Lunches."

97 Heath, John F. Kennedy, 78. 
lessons created a permanent partisan divide regarding the usage of images of Sweden.

Although both Reuther and Goldberg recognized the importance of long legacies in building a Swedish-style negotiative economy, the intoxicating spirit of renewal surrounding Kennedy's election led the labor-liberals to overestimate the ability of the American economy and, in particular, the will of industrial actors to change. Had their attempts at restructuring the American economy around cooperative, centralized lines proved successful, the early 1960s would have signified a major turning point in the wider expanse of American politics and society. However, such dreams were cruelly shattered by the necessity of political compromise and the intransigence of existing interests, both amongst employers and labor. Scandinavian lessons were unable to overcome existing brown field institutions within industrial relations and economic policy, and were largely abandoned at the modelling phase of the lesson drawing process. The incomplete results of the transnational moment seem to reinforce Rose's warning about the inadequacy of drawing lessons from ideologically discordant systems. Yet, the assignment of ideological compatibility between Sweden and the US in the early 1960s was one of the labor-liberals' most successful achievements. Given converging goals to the US, the Scandinavian lessons became powerful symbolic proxies for the ideals of the labor-liberals, who believed in the possibility of transnational transfer. Their commitment serves as a reminder of the potential discursive and ideational importance of small states in American policymaking.

\section{Bibliography}

Archive abbreviations:

Goldberg: Arthur J. Goldberg Papers, Manuscript Division, Library of Congress, Washington, D.C.

NARA: National Archives of the United States II, College Park, Maryland.

Schlesinger: Esther Peterson Papers, 1884-1998; Schlesinger Library, Radcliffe Institute, Harvard University.

Reuther: Walter P. Reuther Library, University Archives, Wayne State University

\section{Literature:}

“A Leader Must Lead.” Business Week, March 17, 1962.

Andersson, Jenny. "Nordic Nostalgia and Nordic Light: The Swedish Model as Utopia 1930-2007." Scandinavian Journal of History 34, no. 3 (September 23, 2009): 229-45. 
https://doi.org/10.1080/03468750903134699.

Andersson, Jenny, and Mary Hilson. "Images of Sweden and the Nordic Countries." Scandinavian Journal of History 34, no. 3 (September 23, 2009): 219-28.

https://doi.org/10.1080/03468750903134681.

Berendt, Gerald, Gil Cornfield, and Peter Edelman. “Arthur J. Goldberg's Legacies to American Labor Relations." The John Marshall Law Review 32, no. 3 (1999): 667-723.

Bernstein, Irving. Promises Kept: John F. Kennedy's New Frontier. New York: Oxford University Press, 1991.

Boyle, Kevin, ed. Organized Labor and American Politics, 1894-1994: The Labor-Liberal Alliance. Albany, NY: State University of New York Press, 1998.

- - - . The UAW and the Heyday of American Liberalism 1945-1968. Ithaca, NY: Cornell University Press, 1995.

Carew, Anthony. Walter Reuther. Manchester: Manchester University Press, 1993.

Carlbom, Mats. "Palme Och Geijer, Finfina Grejer." Dagens Nyheter, March 4, 2003.

http://www.dn.se/nyheter/politik/palme-och-geijer-finfina-grejer/.

Cheshire, Maxine. "Equal Pay Will Come Gradually: Free Speech Is Democratic." Washington Post, October 3, 1962.

Childs, Marquis W. This Is Democracy: Collective Bargaining in Scandinavia. New Haven: Yale University Press, 1938.

Clayton, Rennie E. "Collective Bargaining in Sweden." Journal of Industrial Relations 1, no. 2 (October 1, 1959): 98-110. https://doi.org/10.1177/002218565900100204.

Dallek, Robert. An Unfinished Life: John F. Kennedy, 1917-1963. Boston: Little, Brown, and Co., 2003.

Dubofsky, Melvyn. The State \& Labor in Modern America. Chapel Hill: University of North Carolina Press, 1994.

Einhorn, Eric S., and John Logue. "Can Welfare States Be Sustained in a Global Economy? Lessons from Scandinavia." Political Science Quarterly 125, no. 1 (2010): 1-29.

Fossat, Sissel Bjerrum. "The American Way Eller Den Danske Model: Den Socialdemokratiske Fagbevægelse På Studierejse Til Amerika under Marshall-Planen." In Transnationale Historier, edited by Sissel Bjerrum Fossat, Anne Magnussen, Klaus Petersen, and Nils Arne Sørensen, 213-29. Odense: Syddansk Universitetsforlag, 2009.

Glover, Nikolas. "Imaging Community: Sweden in 'Cultural Propaganda' Then and Now." Scandinavian Journal of History 34, no. 3 (September 23, 2009): 246-63. https://doi. org/10.1080/03468750903134707.

- - - National Relations: Public Diplomacy, National Identity and the Swedish Institute, 1945-1970. Lund: Nordic Academic Press, 2012.

“Goldberg Hails Swedes.” New York Times, September 23, 1961.

"Goldberg Plans to Visit Sweden." The Washington Post, April 5, 1961.

Goldwater, Barry. "There Are No Free Lunches.” Los Angeles Times, October 21, 1966.

Harvard, Jonas, and Peter Stadius. "A Communicative Perspective on the North: Contexts, Channels and Concepts." In Communicating the North: Media Structures and Images in the Making of the Nordic Region, edited by Jonas Harvard and Peter Stadius, 1-24. Farnham: Ashgate, 2013.

Heath, Jim F. John F. Kennedy and the Business Community. Chicago: University Of Chicago Press, 1969.

Hilson, Mary. The Nordic Model: Scandinavia since 1945. London: Reaktion Books, 2008.

Houe, Poul, and Sven Hakon Rossel. Images of America in Scandinavia. Amsterdam: Rodopi, 1998.

Kastrup, Allan. Med Sverige i Amerika: Opinioner, Stamningar och Upplysningsarbete: En 
Rapport. Malmö: Corona, 1985.

"Keep Hands Off." Business Week, March 17, 1962.

Lester, Richard A. "Reflections on Collective Bargaining in Britain and Sweden." Industrial and Labor Relations Review 10, no. 3 (1957): 375-401 . https://doi.org/10.2307/2519772.

Levitan, Sar A. Federal Aid to Depressed Areas: An Evaluation of the Area Redevelopment Administration. Baltimore: Johns Hopkins, 1964.

Lichtenstein, Nelson. State of the Union: A Century of American Labor. Princeton, N.J.: Princeton University Press, 2002.

- - - "Walter Reuther and the Rise of Labor-Liberalism." In Labor Leaders in America, edited by Melvyn Dubofsky and Warren Van Tine, 280-302. Urbana: University of Illinois Press, 1987.

_- - Walter Reuther: The Most Dangerous Man in Detroit. Urbana: University of Illinois Press, 1995.

Logue, John. "The Swedish Model: Visions of Sweden in American Politics and Political Science." Swedish-American Historical Quarterly 50, no. 3 (1999): 162-72.

Maraniss, David. Once in a Great City: A Detroit Story. New York: Simon and Schuster, 2015.

Marklund, Carl. "A Swedish Norden or a Nordic Sweden? Image Politics in the West during the Cold War." In Communicating the North: Media Structures and Images in the Making of the Nordic Region, edited by Jonas Harvard and Peter Stadius, 263-87. Farnham: Ashgate, 2013.

- _ - "The Social Laboratory, the Middle Way and the Swedish Model: Three Frames for the Image of Sweden." Scandinavian Journal of History 34, no. 3 (September 23, 2009): 264-85.

https://doi.org/10.1080/03468750903134715.

Marklund, Carl, and Klaus Petersen. "Return to Sender - American Images of the Nordic Welfare States and Nordic Welfare State Branding." European Journal of Scandinavian Studies 43, no. 2 (2013): 245-57.

Molin, Björn. "Sweden: Politics Since 1964." Scandinavian Political Studies 2 (January 1, 1967): 253-56.

Musiał, Kazimierz. Tracing Roots of the Scandinavian Model: Image of Progress in the Era of Modernisation. Florence: European University Institute, 1998.

Myers, Charles A. Industrial Relations in Sweden: Some Comparisons with American Experience. Cambridge: Massachusetts Institute of Technology Press, 1951.

Nickell, Stephen, Luca Nunziata, and Wolfgang Ochel. "Unemployment in the OECD since the 1960s. What Do We Know?" The Economic Journal 115, no. 500 (2005): 1-27.

OECD. "OECD.Stat." oecd.stat.org. Accessed February 14, 2017.

https://stats.oecd.org/Index.aspx?DataSetCode=UN_DEN\#. Accessed 29 December 2017.

Oettinger, Martin P. "Collective Bargaining, Wage Restraint, and National Economic Policy: A Comparative Study of the United States and Western Europe." Economic Inquiry 2, no. 3 (June 1, 1964): 233-55. https://doi.org/10.1111/j.1465-7295.1964.tb01055.x.

Olesen, Thorsten Borring. "The Dilemmas of Interdependence: Danish Foreign Policy 1945-1972." Journal of European Integration History 7, no. 2 (2001): 37-64.

Opotowsky, Stan. The Kennedy Government. New York: E.P. Dutton, 1961.

Östberg, Kjell, and Jenny Andersson. Sveriges Historia, 1965-2012, 2013.

Perlstein, Rick. Before the Storm: Barry Goldwater and the Unmaking of the American Consensus. New York: Hill and Wang, 2001.

Plotke, David. "The Wagner Act, Again: Politics and Labor, 1935-37." Studies in American Political Development 3 (1989): 105-56. 
President's Commission on the Status of Women. American Women: Report of President's Commission the Status of Women. Washington D.C.: U.S. Government Printing Office, 1963.

Rasmussen, Hanne, and Mogens Rüdiger. Danmarks Historie: Tiden Efter 1945. Danmarks Historie. Copenhagen: Gyldendal, 1990.

Reeves, Richard. President Kennedy: Profile of Power. New York: Simon and Schuster, 1993.

Rose, Richard. Learning from Comparative Public Policy: A Practical Guide. London: Routledge, 2005.

- - - Lesson-Drawing in Public Policy: A Guide to Learning Across Time and Space. Chatham, NJ: Chatham House Publishers, 1993.

- - - . "Ten Steps in Learning Lessons from Abroad." European University Institute, Robert Schuman Centre for Advanced Studies, 2002. Accessed December 29, 2017.

http://cadmus.eui.eu/bitstream/handle/1814/1763/RSCAS_2002_05b. pdf? sequence $=1 \&$ is Allowed $=y$.

Schnitzer, Martin. "Programs for Relocating Workers Used by Governments of Selected Countries." Economic Policies and Practices. Washington, D.C.: Joint Economic Committee, 1966. Accessed December 29. 2017.

http://www.jec.senate.gov/reports/89th\%20Congress/Other\%20Reports/Programs\%20 for $\% 20$ Relocating $\% 20$ Workers $\% 20$ Used $\% 20$ by $\% 20$ Governments $\% 20$ of $\% 20$ Selected\%20Countries\%20(304).pdf,

Sejersted, Francis. The Age of Social Democracy: Norway and Sweden in the Twentieth Century. Edited by Madeline B. Adams. Translated by Richard Daly. Princeton: Princeton University Press, 2011.

Shelton, Isabelle. "Swedish System Inspires U.S. Labor Officials." Washington D.C. Star, August 20, 1961. Esther Peterson Papers, 1884-1998, MC 450, Folder: 1228. Schlesinger Library (Schlesinger), Radcliffe Institute, Harvard University.

Sorensen, Theodore C. Kennedy. London: Hodder and Stoughton, 1965.

Special Committee on Aging. "Housing for the Elderly: A Report of the Committee on Housing for the Elderly to the Special Committee on Aging, United States Senate." Washington D.C.: U.S. Government Printing Office, 1962.

Stadius, Peter. "Happy Countries: Appraisals of Interwar Nordic Societies." In Communicating the North: Media Structure and Images in the Making of the Nordic Region, edited by Jonas Harvard and Peter Stadius, 241-62. Farnham: Ashgate, 2013.

Stebenne, David. Arthur J. Goldberg: New Deal Liberal. New York: Oxford University Press, 1996.

Storing, James A. Norwegian Democracy. Boston: Houghton Mifflin, 1963.

Strout, Richard L. "Growth Rate...a Nudge." Christian Science Monitor, February 14, 1961.

Tolliday, Steven, and Jonathan Zeitlin. "Shop Floor Bargaining, Contract Unionism, and Job Control: An Anglo-American Comparison." In On the Line: Essays in the History of Auto Work, edited by Nelson Lichtenstein and Stephen Meyer, 219-44. Urbana: University of Illinois Press, 1989.

Townsend, Ed. "People at Work: Labor, Management Get Word." Christian Science Monitor, October 14, 1961. 